\title{
Bibliography of papers from studies undertaken in Africa and published in Public Health Nutrition, 1998 to date
}

1 Adish AA, Esrey SA, Gyorkos TW, Johns T. Risk factors for iron deficiency anaemia in preschool children in northern Ethiopia. Public Health Nutrition 1999; 2(3): 243-52.

2 Aguayo VM, Kone D, Bamba SI, Diallo B, Sidibe Y, Traore D, Signe P, Baker SK. Acceptability of multiple micronutrient supplements by pregnant and lactating women in Mali. Public Health Nutrition 2005; 8(1): 33-7.

3 Aguayo VM, Kahn S, Ismael C, Meershoek S. Vitamin A deficiency and child mortality in Mozambique. Public Health Nutrition 2005; 8(1): 29-31.

4 Aguayo VM, Scott S, Ross J; PROFILES Study Group. Sierra Leone - investing in nutrition to reduce poverty: a call for action. Public Health Nutrition 2003; 6(7): 653-7.

5 Amoah AG. Sociodemographic variations in obesity among Ghanaian adults. Public Health Nutrition 2003; 6(8): 751-7.

6 Ayoya MA, Mandimika T, Mbuya M, Mbuya N, MensahHomiah J, Garza C. The African Nutrition Graduate Students Network: a new initiative for nutrition in Africa. Public Health Nutrition 2004; 7(2): 359

7 Barr F, Brabin L, Agbaje S, Buseri F, Ikimalo J, Briggs N. Reducing iron deficiency anaemia due to heavy menstrual blood loss in Nigerian rural adolescents. Public Health Nutrition 1998; 1(4): 249-57.

8 Belahsen R, Mziwira M, Fertat F. Anthropometry of women of childbearing age in Morocco: body composition and prevalence of overweight and obesity. Public Health Nutrition 2004; 7(4): 523-30.

9 Benefice E, Caius N, Garnier D. Cross-cultural comparison of growth, maturation and adiposity indices of two contrasting adolescent populations in rural Senegal (West Africa) and Martinique (Caribbean). Public Health Nutrition 2004; 7(4): 479-85.

10 Benjelloun S. Nutrition transition in Morocco. Public Health Nutrition 2002; 5(1A): 135-40.

11 Boonstra E, Lindbaek M, Fidzani B, Bruusgaard D. Cattle eradication and malnutrition in under five's: a natural experiment in Botswana. Public Health Nutrition 2001; 4(4) 877-82.

12 Bourne LT, Lambert EV, Steyn K. Where does the black population of South Africa stand on the nutrition transition? Public Health Nutrition 2002; 5(1A): 157-62.

13 Brussaard JH, van Erp-Baart MA, Brants HA, Hulshof KF, Lowik MR. Nutrition and health among migrants in The Netherlands. Public Health Nutrition 2001; 4(2B): 659-64.

14 Charlton KE, Brewitt P, Bourne LT. Sources and credibility of nutrition information among black urban South African women, with a focus on messages related to obesity. Public Health Nutrition 2004; 7(6): 801-11.

15 Charlton KE, Rose D. Prevalence of household food poverty in South Africa: results from a large, nationally representative survey. Public Health Nutrition 2002; 5(3): 383-9.

16 Chilima DM, Ismail SJ. Nutrition and handgrip strength of older adults in rural Malawi. Public Health Nutrition 2001; 4(1): 1-7.

17 Chopra M. Risk factors for undernutrition of young children in a rural area of South Africa. Public Health Nutrition 2003; 6(7): 645-52.

18 Colecraft EK, Marquis GS, Bartolucci AA, Pulley L, Owusu WB, Maetz HM. A longitudinal assessment of the diet and growth of malnourished children participating in nutrition rehabilitation centres in Accra, Ghana. Public Health Nutrition 2004; 7(4): 487-94.

19 Dannhauser A, Bester C, Joubert G, Badenhorst P, Slabber M, Badenhorst A, Du Toit E, Barnard H, Botha P, Nogabe L.
Nutritional status of preschool children in informal settlement areas near Bloemfontein, South Africa. Public Health Nutrition 2000; 3(3): 303-12.

20 Darmon N, Khlat M. An overview of the health status of migrants in France, in relation to their dietary practices. Public Health Nutrition 2001; 4(2): 163-72.

21 Darnton-Hill I, Coyne ET. Feast and famine: socioeconomic disparities in global nutrition and health. Public Health Nutrition 1998; 1(1): 23-31.

22 Delpeuch F, Traissac P, Martin-Prevel Y, Massamba JP, Maire B. Economic crisis and malnutrition: socioeconomic determinants of anthropometric status of preschool children and their mothers in an African urban area. Public Health Nutrition 2000; 3(1): 39-47.

23 Dop MC, Simondon KB. Breast-feeding in sub-Saharan Africa: outlook for 2000. Public Health Nutrition 2001; 4(4): 929-32.

24 Egbuta J, Onyezili F, Vanormelingen K. Impact evaluation of efforts to eliminate iodine deficiency disorders in Nigeria. Public Health Nutrition 2003; 6(2): 169-73.

25 Faber M, Venter SL, Benade AJ. Increased vitamin A intake in children aged $2-5$ years through targeted home-gardens in a rural South African community. Public Health Nutrition 2002; 5(1): 11-6.

26 Faber M, Spinnler Benade AJ. Factors associated with low serum retinol levels in children aged 6-24 months in a rural South African community. Public Health Nutrition 2000; 3(4): 395-402.

27 Faber M, Benade AJ. Nutritional status and dietary practices of 4-24-month-old children from a rural South African community. Public Health Nutrition 1999; 2(2): 179-85.

28 Fouere T, Maire B, Delpeuch F, Martin-Prevel Y, Tchibindat F, Adoua-Oyila G. Dietary changes in African urban households in response to currency devaluation: foreseeable risks for health and nutrition. Public Health Nutrition 2000; 3(3): 293-301.

29 Galal OM. The nutrition transition in Egypt: obesity, undernutrition and the food consumption context. Public Health Nutrition 2002; 5(1A): 141-8.

30 Garnier D, Simondon KB, Hoarau T, Benefice E. Impact of the health and living conditions of migrant and non-migrant Senegalese adolescent girls on their nutritional status and growth. Public Health Nutrition 2003; 6(6): 535-47.

31 Hall A, Roschnik N, Ouattara F, Toure I, Maiga F, Sacko M, Moestue H, Bendech MA. A randomised trial in Mali of the effectiveness of weekly iron supplements given by teachers on the haemoglobin concentrations of schoolchildren. Public Health Nutrition 2002; 5(3): 413-8.

32 Hall A, Bobrow E, Brooker S, Jukes M, Nokes K, Lambo J, Guyatt H, Bundy D, Adjei S, Wen ST, Satoto, Subagio H, Rafiluddin MZ, Miguel T, Moulin S, de Graft Johnson J, Mukaka M, Roschnik N, Sacko M, Zacher A, Mahumane B, Kihamia C, Mwanri L, Tatala S, Lwambo N, Siza J, Khanh LN, Khoi HH, Toan ND. Anaemia in schoolchildren in eight countries in Africa and Asia. Public Health Nutrition 2001; 4(3): 749-56.

33 Hampshire RD, Aguayo VM, Harouna H, Roley JA, Tarini A, Baker SK. Delivery of nutrition services in health systems in sub-Saharan Africa: opportunities in Burkina Faso, Mozambique and Niger. Public Health Nutrition 2004; 7(8): $1047-53$.

34 Hatloy A, Hallund J, Diarra MM, Oshaug A. Food variety, socioeconomic status and nutritional status in urban anc 
rural areas in Koutiala (Mali). Public Health Nutrition 2000; 3(1): 57-65.

35 Heald AH, Cade JE, Cruickshank JK, Anderson S, White A, Gibson JM. The influence of dietary intake on the insulin-like growth factor (IGF) system across three ethnic groups: a population-based study. Public Health Nutrition 2003; 6(2): $175-80$

36 Hendricks MK, Roux ML, Fernandes M, Irlam J. Evaluation of a nutrition supplementation programme in the Northern Cape Province of South Africa. Public Health Nutrition 2003; 6(5): 431-7.

37 Jackson M, Walker S, Cade J, Forrester T, Cruickshank JK, Wilks R. Reproducibility and validity of a quantitative foodfrequency questionnaire among Jamaicans of African origin. Public Health Nutrition 2001; 4(5): 971-80.

38 Jinabhai CC, Taylor M, Coutsoudis A, Coovadia HM, Tomkins AM, Sullivan KR. Epidemiology of helminth infections: implications for parasite control programmes, a South African perspective. Public Health Nutrition 2001; 4(6): 1211-9.

39 Kaluski DN, Ophir E, Amede T. Food security and nutrition the Ethiopian case for action. Public Health Nutrition 2002; 5(3): 373-81.

40 Kidala D, Greiner T, Gebre-Medhin M. Five-year follow-up of a food-based vitamin A intervention in Tanzania. Public Health Nutrition 2000; 3(4): 425-31.

41 Kruger R, Gericke GJ. A qualitative exploration of rural feeding and weaning practices, knowledge and attitudes on nutrition. Public Health Nutrition 2003; 6(2): 217-23.

42 Kumar BN, Holmboe-Ottesen G, Lien N, Wandel M. Ethnic differences in body mass index and associated factors of adolescents from minorities in Oslo, Norway: a cross-sectional study. Public Health Nutrition 2004; 7(8): 999-1008.

43 Lakati A, Binns C, Stevenson M. Breast-feeding and the working mother in Nairobi. Public Health Nutrition 2002; 5(6): 715-8.

44 Landman J, Cruickshank JK. A review of ethnicity, health and nutrition-related diseases in relation to migration in the United Kingdom. Public Health Nutrition 2001; 4(2B): $647-57$

45 Lemke S, Vorster HH, van Rensburg NS, Ziche J. Empowered women, social networks and the contribution of qualitative research: broadening our understanding of underlying causes for food and nutrition insecurity. Public Health Nutrition 2003; 6(8): 759-64.

46 Lezama I, Lockwood K, Bergmann T; Togo Internship Project 1997, UNICEF-Togo. United Nations Children's Fund. Nutrition intervention strategies in chronically malnourished regions: preventing endemic goitre in Togo. Public Health Nutrition 2001; 4(6A): 1415-9.

47 MacIntyre UE, Venter CS, Vorster HH. A culture-sensitive quantitative food frequency questionnaire used in an African population: 2 . Relative validation by 7 -day weighed records and biomarkers. Public Health Nutrition 2001; 4(1): 63-71.

48 MacIntyre UE, Venter CS, Vorster HH. A culture-sensitive quantitative food frequency questionnaire used in an African population: 1. Development and reproducibility. Public Health Nutrition 2001; 4(1): 53-62.

49 MacIntyre UE, Venter CS, Vorster HH, Steyn HS. A combination of statistical methods for the analysis of the relative validation data of the quantitative food frequency questionnaire used in the THUSA study. Transition, Health and Urbanisation in South Africa. Public Health Nutrition 2001; 4(1): 45-51

50 MacKeown JM, Faber M. Urbanisation and cariogenic food habits among 4-24-month-old black South African children in rural and urban areas. Public Health Nutrition 2002; 5(6): 719-26.

51 MacKeown JM, Cleaton-Jones PE, Edwards AW. Energy and macronutrient intake in relation to dental caries incidence in urban black South African preschool children in 1991 and 1995: the Birth-to-Ten study. Public Health Nutrition 2000; 3(3): 313-9.

52 Maletnlema TN. A Tanzanian perspective on the nutrition transition and its implications for health. Public Health Nutrition 2002; 5(1A): 163-8.

53 Manuela de Paoli M, Manongi R, Klepp KI. Are infant feeding options that are recommended for mothers with HIV acceptable, feasible, affordable, sustainable and safe? Pregnant women's perspectives. Public Health Nutrition 2004; 7(5): 611-9.

54 Margetts B. Consequences of malnutrition on human capital and productivity. Public Health Nutrition 2003; 6(7): $623-4$.

55 Mennen LI, Jackson M, Sharma S, Mbanya JC, Cade J, Walker S, Riste L, Wilks R, Forrester T, Balkau B, Cruickshank K. Habitual diet in four populations of African origin: a descriptive paper on nutrient intakes in rural and urban Cameroon, Jamaica and Caribbean migrants in Britain. Public Health Nutrition 2001; 4(3): 765-72.

56 Moursi M, Mbemba F, Treche S. Does the consumption of amylase-containing gruels impact on the energy intake and growth of Congolese infants? Public Health Nutrition 2003; 6(3): $249-58$.

57 Nthangeni G, Steyn NP, Alberts M, Steyn K, Levitt NS, Laubscher R, Bourne L, Dick J, Temple N. Dietary intake and barriers to dietary compliance in black type 2 diabetic patients attending primary health-care services. Public Health Nutrition 2002; 5(2): 329-38.

58 Oelofse A, Van Raaij JM, Benade AJ, Dhansay MA, Tolboom JJ, Hautvast JG. Disadvantaged black and coloured infants in two urban communities in the Western Cape, South Africa differ in micronutrient status. Public Health Nutrition 2002; 5(2): 289-94.

59 Onabolu AO, Oluwole OS, Bokanga M, Rosling $\mathrm{H}$. Ecological variation of intake of cassava food and dietary cyanide load in Nigerian communities. Public Health Nutrition 2001; 4(4): 871-6.

60 Onabolu A, Bokanga M, Tylleskar T, Rosling H. High cassava production and low dietary cyanide exposure in mid-west Nigeria. Public Health Nutrition 2001; 4(1): 3-9.

61 Parr CL, Barikmo I, Torheim LE, Ouattara F, Kaloga A, Oshaug A. Validation of the second version of a quantitative food-frequency questionnaire for use in Western Mali. Public Health Nutrition 2002; 5(6): 769-81.

62 Pieterse S, Manandhar M, Ismail S. The nutritional status of older Rwandan refugees. Public Health Nutrition 1998; 1(4): 259-64.

63 Popkin BM. The shift in stages of the nutrition transition in the developing world differs from past experiences! Public Health Nutrition 2002; 5(1A): 205-14.

64 Popkin BM. An overview on the nutrition transition and its health implications: the Bellagio meeting. Public Health Nutrition 2002; 5(1A): 93-103.

65 Rocquelin G, Tapsoba S, Kiffer J, Eymard-Duvernay S. Human milk fatty acids and growth of infants in Brazzaville (The Congo) and Ouagadougou (Burkina Faso). Public Health Nutrition 2003; 6(3): 241-8.

66 Schemann JF, Banou A, Malvy D, Guindo A, Traore L, Momo G. National immunisation days and vitamin A distribution in Mali: has the vitamin A status of pre-school children improved? Public Health Nutrition 2003; 6(3): 233-44.

67 Shirima R, Greiner T, Kylberg E, Gebre-Medhin M. Exclusive breast-feeding is rarely practised in rural and urban Morogoro, Tanzania. Public Health Nutrition 2001; 4(2): $147-54$.

68 Sibeko LN, Dhansay MA, Charlton KE, Johns T, Van Stuijvenberg ME, Gray-Donald K. Full-term, peri-urban South African infants under 6 months of age are at risk for 
early-onset anaemia. Public Health Nutrition 2004; 7(6) 813-20.

69 Steyn NP, Nel JH, Casey A. Secondary data analyses of dietary surveys undertaken in South Africa to determine usual food consumption of the population. Public Health Nutrition 2003; 6(7): 631-44.

70 Torheim LE, Barikmo I, Hatloy A, Diakite M, Solvoll K, Diarra MM, Oshaug A. Validation of a quantitative food-frequency questionnaire for use in Western Mali. Public Health Nutrition 2001; 4(6): 1267-77.

71 van Stuijvenberg ME, Dhansay MA, Smuts CM, Lombard CJ, Jogessar VB, Benade AJ. Long-term evaluation of a micronutrient-fortified biscuit used for addressing micronutrient deficiencies in primary school children. Public Health Nutrition 2001; 4(6): 1201-9.

72 van't Riet H, den Hartog AP, Staveren WA. Non-home prepared foods: contribution to energy and nutrient intake of consumers living in two low-income areas in Nairobi. Public Health Nutrition 2002; 5(4): 515-22.

73 Vorster HH, Kruger A, Margetts BM, Venter CS, Kruger HS, Veldman FJ, Macintyre UE. The nutritional status of asymptomatic HIV-infected Africans: directions for dietary intervention? Public Health Nutrition 2004; 7(8): 1055-64.

74 Vorster HH. The emergence of cardiovascular disease during urbanisation of Africans. Public Health Nutrition 2002, 5(1A): $239-43$.
75 Vorster HH, Jerling JC, Steyn K, Badenhorst CJ, Slazus W, Venter CS, Jooste PL, Bourne LT. Plasma fibrinogen of black South Africans: the BRISK study. Public Health Nutrition 1998; 1(3): 169-76.

76 Walker AR, Adam FI. Breast-feeding in sub-Saharan Africa: outlook for 2000. Public Health Nutrition 2000; 3(3): 285-92.

77 Walsh C, Dannhauser A, Joubert G. The impact of a nutrition education programme on the anthropometric nutritional status of low-income children in South Africa. Public Health Nutrition 2000; 5(1): 3-9.

78 Wolmarans P, Dhansay MA, Mansvelt EP, Laubscher JA, Benade AJ. Iron status of South African women working in a fruit-packing factory. Public Health Nutrition 2003; 6(5): 439-45.

79 Wolmarans P, Seedat YK, Mayet FG, Joubert G, Wentzel E. Dietary intake of Indians living in the metropolitan area of Durban. Public Health Nutrition 1999; 2(1): 55-60.

80 Wright J, Vaze P, Russell G, Gundry SW, Ferro-Luzzi A, Mucavele P, Nyatsanza J. Seasonal aspects of weight-for-age in young children in Zimbabwe. Public Health Nutrition 2001; 4(3): 757-64

81 Zagre NM, Delpeuch F, Traissac P, Delisle H. Red palm oil as a source of vitamin A for mothers and children: impact of a pilot project in Burkina Faso. Public Health Nutrition 2003; 6(8): $733-42$ 